\title{
Toxicity of Aqueous Extract of Desert Date (Balanites Aegyptiaca Linnaeus) On the Juveniles of Catfish (Clarias Gariepinus Teugels, 1986).
}

\author{
Keziah V. Absalom ${ }^{1}$, Patience O. Nwadiro ${ }^{2}$ and Nentawe Wophill ${ }^{1}$ \\ Department of Zoology ${ }^{l}$ University of Jos. \\ Department of Plant science ${ }^{2}$ University of Jos.
}

\begin{abstract}
An investigation was conducted on the toxic effects of the fruit extract of (Balanites aegyptiaca $L$.) on the mortality and behaviour of juveniles of African catfish (Clarias gariepinus). In the acute lethal toxicity study, the fish were exposed to different concentration levels of 64.0, 32.0, 16.0, 08.0, 04.0 and $0.00 \mathrm{gL}^{-1}$ (control) of the fruit extract. A positive correlation ( $r=0.9811)$ was observed between fish mortality and the various concentrations used. Prior to death of fish, some behavioural activities observed were erratic swimming on the water surface, loss of reflex and hyperventilation. Haemoglobin estimation and packed cell volume $(P C V)$ values were significant $(P<0.05)$ for acute lethal toxic dose. The $96 \mathrm{~h}-L C_{50}$ value of the fruit extract was obtained as $12.59 \mathrm{gL}^{-1}$, with lower and upper confidence limits of $7.87 \mathrm{gL}^{-1}$ and $20.14 \mathrm{gL} \mathrm{L}^{-1}$ respectively. Phytochemical analysis showed that the fruit contained saponins, flavonoids, cardiac glycosides, tannins and carbohydrates. In conclusion, solution of the fruit extract caused fish mortality, and its toxic effects lowered the values of some haematological parameters compared to the control group.
\end{abstract}

Key Words: Balanites aegyptiaca, Clarias gariepinus, haematology, acute toxicity.

\section{Introduction}

The knowledge and use of toxic plants is still vital for the current technologically unsophisticated human populations. This applies especially to the ichthyotoxic plants (22, 30 and 13). Bio-degradable alternatives (ichthyotoxic plants), are therefore preferred to remove unwanted fish and other aquatic species from water bodies. Many plants have medicinal properties and they have been used as base chemicals in pharmaceutical industries as documented by (35). Man has always regarded plants as one of the most valued components of the biosphere because of their uses as food and medicine and their chemical values. Of particular interest is Balanites aegyptiaca (commonly referred to as soap beery plant) which contains steroidal saponins (25). In many regions of the world, plant originated fish poison or ichthyotoxic plants are used to stun or kill fish (7, 19 and 10). The trunks, roots, leaves, and seed or fruit of ichthyotoxic plants are used as toxic substances. Fish toxicants are generally used in small and slow running waters inlet and gulf (4). In Nigeria, obnoxious fishing method involve the use of ichthyotoxic plant to catch fish causing mass mortality of fish in ponds, contaminating the freshwater bodies and affecting non-target organisms (23). The physical and chemical changes in aqueous environment often cause some physiological changes in fish, thus, the water quality of an aquatic body is very crucial because it determines the productivity of and other parameters necessary for fish survival. Many countries have legislated against the use of chemical poisons in aquatic systems and have imposed policies favouring the use of natural bio-degradable alternatives to remove unwanted fish species in aquatic systems. Environmental factors such as $\mathrm{pH}$, turbidity, alkalinity, dissolved oxygen, temperature and conductivity influence the rate of reaction of pollutants entering the water (11). Lethal factors restrict the range of the environment in which organisms can exist and beyond this range, metabolism is destroyed (26). Chemical anaesthetics may however, have deleterious effects on fish; these unwanted effects of anaesthetics may be greater on fingerlings than on adult fish (21). To solve the problem of scarce and expensive anesthetics, (9) reported that $4.0 \mathrm{~g} / \mathrm{L}$ of powdered leaves of Erythrophleum suaveolens soaked in water anaesthetized African sharptooth catfish juveniles in 52 minutes. The toxic effects of Crotocaudin extract from the medicinal plant Croton tiglium on the non-target freshwater fish Channa punctalus showed significant alterations in the metabolism of the muscles, liver and gonad tissues. But after withdrawal of Crotocaudin, the fish tissues recovered completely (36). Zebrafish is increasingly used in drug screening and toxicological studies in recent years. It is a useful model of choice for in vivo pharmacodynamic screening and toxicity investigation of Chinese medicine and it has a wide application prospect in the field of $n$ herbal- drug research (20). Acute toxicity tests of water extracts of sausage plant (Kigelia africana) and Akee apple (Blighia sapida) on African catfish (Clarias gariepinus) were carried out by (27), and observed that the acute concentrations of the plant water extracts caused mortality and increased tail and fin beats and opercular beat of the Clarias gariepinus. The fish exhibited stressful behaviours such as erratic movements, gulping of air, loss of balance and often death. 
These behaviours suggested respiratory impairment, probably due to the effect of the toxicants on the gills and general metabolism of the fish. The water extract of bark of B. sapida was the most toxic and had the lowest value of $96-\mathrm{h} \mathrm{LC}_{50}(8.3176 \mathrm{mg} / \mathrm{L})$ as well as the lowest threshold value of $7.5 \mathrm{mg} / \mathrm{L}$. Juveniles of Clarias gariepinus exposed to sublethal concentration of the root extract of Derris elliptica exhibited some behaviours like erratic swimming, loss of reflex, hyperventilation, increased surfacing frequency and jerky movements (23). The aim of this study is to determine the effects of aqueous fruit extract of Balanites aegyptiaca on the behaviour and some haematological parameters of juneviles of African catfish ( Clarias gariepinus) in static bioassay.

\section{Collection And Acclimatization Of Experimental Fish}

\section{Materials And Methods}

Juveniles of Clarias gariepinus (mean weight $10 \pm 0.03 \mathrm{~g}$ ) were collected from Renajj Fishfarm Rayfield, Jos South Local Government Area Jos, Plateau State. The fish were transported in an oxygenated polythene bag, containing water from the pond to the Hydrobiology and Fisheries laboratory unit of the University of Jos, where they were transferred into aquaria containing dechlorinated municipal tap-water and were allowed to acclimatize to the laboratory conditions for a period of two weeks. During this period of acclimatization they were fed with a commercial fish feed (Vital fish feed) from Grand Cereals and Oil Mills Company, Jos.

\section{Experimental Design For Static Bioassay}

The experimental design consisted of a static system made up of 12 plastic tanks of 35 litre tank capacity, each containing 20 litres of dechlorinated water. Healthy juviniles of $C$. gariepinus selected randomly and weighed for the experiment were not fed for 24 hours prior to the start of the experiment. Ten fish were stocked per test tank for the acute bioassay. Dead fish, excess food and faecal materials were removed immediately to reduce pollution in the test water. Two of the tanks served as control.

\section{Extraction Of The Fruit Mesocarp}

The fruits were collected from the plant in villages around Jos, and were taken to the

Herbarium section of the Federal College of Forestry, Jos, where they were identified as fruits of Balanites aegyptiaca. The epicarps were removed to expose the mesocarp of the fruit. $200 \mathrm{~g}$ of the mesocarp was dissolved in 1 litre of distilled water and allowed to ferment for two days, and this gave a stock solution for further dilutions.

\section{Phytochemical Screening For Active Ingredients}

Phytochemical screening was carried out on the crude fruit (mesocarp) of Balanites aegyptiaca to detect the presence of alkaloids, tannins, saponins, anthraquinones, steroids, flavonoids and cardiac glycosides. Standardized chemical tests as modified by (14) were employed for the screening.

\section{Exposure Of Test Fish To Aqueous Extract Of Fruit (Mesocarp) Of Balanites Aegyptiaca Acute Toxicity}

A total number of twelve (12) plastic tanks each with a capacity of 35 litres were used for the bioassay experiment. Five different acute concentrations were prepared in duplicate. The acute lethal concentrations used were 64.0, 32.0, 16.0, 08.0, 04.0 and $0.00 \mathrm{~g} / \mathrm{L}$ (control). Each of the tanks was stocked with 10 fish of mean weight $(10.0 \pm 0.03 \mathrm{~g})$.

The 96-hour $\mathrm{LC}_{50}$ (lethal concentration) was determined using a probit analysis method for acute toxicity test as recommended by (33). The water quality parameters were

monitored at every 24 hours. Mortality and observed behaviours of the fish were recorded daily. Dead fish were immediately removed from each test tank to avoid polluting the

tanks. The fruit extract concentrations in the various test tanks were renewed daily after changing the water in the test tanks to maintain their potency.

\section{Behavioural Studies And Mortality}

After the test fish were exposed to various concentrations of the fruit extract, the behavioural responses and the mortality rate of the fish were observed and recorded at the intervals of 12, 24, 48, 72 and 96 hours, according to the method developed by (29). The fish in the control tank were monitored and they served as a reference to the behavioural responses observed in those exposed to the different concentrations of the test 
tanks. The responses to be observed if any occurred were general activity, hyperactivity, hypoactivity, loss of equilibrium and death of fish.

\section{Mortality}

Observations on mortality rate of juveniles of Clarias gariepinus were made at 12, 24, 48,

72 and 96hours. Juveniles of C. gariepinus were considered dead when there were no signs of movement and response to external stimuli. Dead fish were removed immediately to prevent pollution in the tanks that could lead to depletion of dissolved oxygen which will affect the remaining fish adversely.

\section{Haematological Studies For Acute Bioassay}

Haematological parameters were determined by the processes described by (15). The Erythrocyte (RBC) count was determined by the collection of blood from the severed peduncle of the fish using the RBC pipette to mark of $0.5(0.005 \mathrm{ml})$. The tip of the pipette was wiped free of blood. Blood collected was introduced into the diluting fluid (Hayem's fluid) in a test tube i.e (1:200), the blood and the diluting fluid were mixed properly and allowed to stay for some minutes.A prepared counting chamber placed on a microscope stage was used for cells count. The Packed Cell Volume (PCV) was determined thus: heparinized micro-haematocrit capillary tubes were filled with blood to about $2 / 3$ of the total length of each of the tube through a capillary force. The tubes were sealed at each of their one end with cristaseal and placed on the haematocrite reader and the results were expressed in percentage. Leucocytes (WBC) count was determined thus: $0.195 \mathrm{ml}$ of

Turke's fluid was pipetted and dispensed into a test tube in the test tube rack. $0.05 \mathrm{ml}$ of blood was drawn from the bleeding peduncle and added to the Turke's fluid in the test tube and mixed properly. A prepared counting chamber placed on a microscope stage was used for cells count.

\section{Results and Discussion}

The phytochemical screening of the fruit (mesocarp) extract of Balanites aegyptiaca revealed the presence of saponins, tannins, cardiac glycosides, flavonoids and carbohydrates. This is in agreement with earlier report by (16), (25), (28) and (10). In this research, the laboratory 96-hour $\mathrm{LC}_{50}$ value of the fruit extract of Balanites aegyptiaca on juveniles of Clarias gariepinus was obtained on the probit graph as $12.59 \mathrm{gL}^{-1}$ with upper and lower confidence limits of 20.14 and $7.87 \mathrm{gL}^{-1}$ respectively (Figure 1). As earlier reported by (29) that $\mathrm{LC}_{50}$ is the convenient reference point for expressing the acute lethal toxicity of a given pollutant to fish. Table 1 showed that percentage mortality of fish exposed to aqueous fruit extract of B. aegyptiaca was dose dependent. Mortality was highest in the highest concentration.

Table 1: Percentage mortality $\left(\mathrm{LC}_{50}\right)$ of Clarias gariepinus exposed to various acute concentrations of the fruit extract of Balanites aegyptiaca.

\begin{tabular}{|c|c|c|c|c|c|}
\hline \multirow[t]{2}{*}{ Concentration (g/L) } & \multicolumn{2}{|c|}{ Mortality rate } & \multirow[b]{2}{*}{$72 \mathrm{~h}$} & \multirow[b]{2}{*}{$96 \mathrm{~h}$} & \multirow[t]{2}{*}{ percentage Mortality (\%) } \\
\hline & & $24 \mathrm{~h} 48 \mathrm{~h}$ & & & \\
\hline Control $(0.00)$ & - & - & - & - & 0 \\
\hline 4.0 & - & - & 1 & 1 & 20 \\
\hline 8.0 & - & - & 1 & 2 & 30 \\
\hline 16.0 & - & - & 2 & 4 & 60 \\
\hline 32.0 & - & 1 & 1 & 5 & 70 \\
\hline 64.0 & 4 & 6 & - & - & 100 \\
\hline
\end{tabular}

N.B Result of 2 replicates over 96 hours

TABLE 2: shows the mean values for some haematological parameters of Clarias gariepinus exposed to acute lethal concentration of fruit extract of Balanites aegyptiaca.The result of this study showed that fruit extract of Balanites aegyptiaca had effect on the haematological parameters of Clarias gariepinus. There was significant $(\mathrm{P}<0.05)$ effect of the fruit extract of $B$. aegyptiaca on the haemoglobin level as well as the packed cell volume level of $C$. gariepinus. While there was no significant effect $(\mathrm{P}>0.05)$ on the leucocyte count, mean corpuscular volume (MCV), mean corpuscular haemoglobin $(\mathrm{MCH})$ and erythrocyte count. Plant derived toxins are known to cause changes in the blood variables ( $\mathrm{Hb}, \mathrm{RBC} . \mathrm{MCV}, \mathrm{MCH}$, and $\mathrm{MCHC}$ ) associated with oxygen transport in fish (2 and 24) and in some cases resulting in anaemia due to destruction or (lysis) of erythrocytes or inhibition of erythropoiesis by the active ingredients in the plant extracts (5). However, there was an increase in erythrocyte count, PCV and $\mathrm{Hb}$, i.e. their mean values increased from control group as shown in table 2. This could be indicative of positive absorption of the fruit extract of B. aegyptiaca by the test fish (23). In fish blood, oxygen is carried in combination with haemoglobin and this is very important for the survival of the fish. (3) observed increase in red blood cells of Clarias species exposed to sublethal concentration of Zinc, while that of 
the Oreochromis species did not increase when exposed to the same concentration of Zinc as toxicant. Haemoglobin estimation of the groups of fish exposed to acute concentrations of the fruit extract of Balanites aegyptiaca showed an increase in mean values of haemoglobin and haematocrit levels compared to that of the control groups, as shown in table 2. The exposed fish in this study were not anaemic as indicated by the mean values of $\mathrm{Hb}, \mathrm{PCV}$ and RBC. This reason could be that the levels of the plant extract did not interfer with the erythropoiesis nor haemolysis. Similar observation was made by (12) when hybrid of catfish (Heterobranchus longifilis) and catfish ( Clarias gariepinus ) were exposed to aqueous extracts of leaves of Lepidagathis alopecuroides. The result of the mean corpuscular volume (MCV) showed that the test fish exposed to the highest concentration of the toxicant $\left(64.0 \mathrm{gL}^{-1}\right)$ had the lowest $\mathrm{MCV}$ value of $58.90 \mathrm{fl}$, while those in the control group had mean value of $294.10 \mathrm{fl}$. This is probably due to spleen contraction in the test fish. (1) reported that spleen contraction after stress had been detected in fish. Cells released from the spleen which is an erythropoietic organ would have lowered MCV value. (3), observed lower MCV values in Clarias gariepinus treated with Zinc salt. A similar observation was made for Cyprinus carpio after Cadmium exposure (18).

TABLE 2: Mean values for some haematological parameters of Clarias gariepinus exposed to acute lethal concentration of fruit extract of Balanites aegyptiaca.

\begin{tabular}{|c|c|c|c|c|c|c|}
\hline \multirow[t]{2}{*}{ Parameter } & \multicolumn{5}{|c|}{ Concentration $(\mathrm{g} / \mathrm{L})$} & \multirow[b]{2}{*}{0.00 (control) } \\
\hline & 64.0 & 32.0 & 16.0 & 8.0 & 4.0 & \\
\hline $\begin{array}{l}\text { Erythrocute } \\
\text { count }\left(\times 10^{6}\right. \\
\left.\text { cells } / \mathrm{mm}^{3}\right)\end{array}$ & $2.60 \pm 0.20$ & $2.40 \pm 0.10$ & $1.80 \pm 0.10$ & $1.50 \pm 0.07$ & $0.70 \pm 0.05$ & $1.70 \pm 0.10$ \\
\hline $\begin{array}{l}\text { Leucocyte count } \\
\left(\times 10^{3} \text { cells } / \mathrm{mm}^{3}\right.\end{array}$ & $1.30 \pm 0.49$ & $1.9 \pm 0.60$ & $2.4 \pm 0.20$ & $1.40 \pm 0.60$ & $2.10 \pm 0.90$ & $2.40 \pm 0.20$ \\
\hline $\begin{array}{l}\text { Haematocrit } \\
(\%)^{*}\end{array}$ & $50.0 \pm 0.00$ & $38.5 \pm 2.01$ & $44.0 \pm 0.10$ & $34.50 \pm 032$ & $30.0 \pm 3.49$ & $14.0 \pm 1.41$ \\
\hline $\operatorname{MCV}(\mathrm{fl})$ & $58.90 \pm 4.70$ & $125.0 \pm 0.01$ & $244.0 \pm 0.13$ & $230.0 \pm 0.20$ & $275.10 \pm 0.30$ & $294.10 \pm 0.00$ \\
\hline $\begin{array}{l}\mathrm{MCHC} \\
(\mathrm{g} / 100 \mathrm{ml})\end{array}$ & $23.60 \pm 3.86$ & $11.73 \pm 0.37$ & $7.55 \pm 0.65$ & $8.41 \pm 0.30$ & $12.90 \pm 2.00$ & $11.60 \pm 3.04$ \\
\hline $\mathrm{MCH}\left(\times 10^{-4} \mathrm{pg}\right)$ & $3.40 \pm 0.32$ & $1.10 \pm 0.13$ & $1.90 \pm 0.01$ & $1.80 \pm 0.30$ & $1.50 \pm 0.00$ & $1.30 \pm 0.02$ \\
\hline $\begin{array}{l}\text { Haemoglobin } \\
(\mathrm{g} / \mathrm{dl})^{*}\end{array}$ & $5.80 \pm 0.13$ & $4.98 \pm 0.30$ & $2.90 \pm 0.01$ & $3.52 \pm 0.20$ & $3.32 \pm 0.05$ & $3.31 \pm 0.13$ \\
\hline
\end{tabular}

* Mean values for some haemotological parameters that were significant $(\mathrm{P}<0.05)$.

Legend:

$\mathrm{MCV}=$ Mean Corpuscular Volume

$\mathrm{MCHC}=$ Mean Corpuscular Haemoglobin Concentration

$\mathrm{MCH}=$ Mean Corpuscular Haemoglobin

Table 3: shows the mean values for water quality parameters during the exposure of Clarias gariepinus to the acute lethal concentrations of the fruit extract of Balanites aegyptiaca for 96hours. Acute lethal concentrations of the fruit extract of Balanites aegyptiaca has effect on some of the water quality parameters. Earlier studies have shown that when water quality is affected by toxicants, any physiological changes would be reflected in the values of one or more of the haematological parameters (34). Therefore water quality is one of the major factors responsible for individual variations in fish haematology, since they live in close association with their environment and are sensitive to slight fluctuation that may occur within internal milieu (6). The plant extract has effect on alkalinity, $\mathrm{pH}$, dissolved oxygen, total ammonia, nitrite and free carbon dioxide but not on temperature and total hardness. Results from the investigation showed that a significant reduction was observed in the mean values of alkalinity and dissolved oxygen when compared with their mean values obtained in the control, but the opposite was observed for total ammonia, nitrite and free carbondioxide mean values, which increased with increase in concentration of the fruit extract. These changes in the physico-chemical parameters could be associated with the effect of the plant extract used. This is in agreement with the earlier report by (12) that when water quality is affected by toxicants, any physiological changes resulting from it will be reflected in the values of one or more of the haematological parameters. Respiratory irregularities are thought to be caused by mucous precipitation on the gill epithelium in response to toxicant and this may result in the decrease in the amount of dissolved oxygen. The erratic swimming, loss of reflex, hyperventilation, increased surface frequency; jerky movement, hanging vertically in the water and lighting in the colur of skin prior to death of fish observed in this investigation may be as a result of respiratory impairment due to the effect of the toxicant on the gill. This is in agreement with the reports of (23) and (17). 
Table 3: The mean values for water quality parameters during the exposure of Clarias gariepinus to the acute lethal concentrations of the fruit extract of Balanites aegyptiaca for 96hours.

Parameter

\begin{tabular}{lllllll} 
Parameter & \multicolumn{5}{c}{ concentration $(\mathrm{g} / \mathrm{L})$} \\
\cline { 2 - 6 } & \multicolumn{1}{c}{64.00} & 32.00 & 16.00 & 8.00 & 4.00 & 0.00 \\
\hline $\mathrm{pH}^{*}$ & $6.75 \pm 0.00$ & $6.75 \pm 0.00$ & $6.50 \pm 0.00$ & $6.67 \pm 0.00$ & $6.50 \pm 0.00$ & $7.00 \pm 0.00$ \\
$\mathrm{DO}(\mathrm{mg} / \mathrm{L})^{*}$ & $1.0 \pm 0.01$ & $1.0 \pm 0.01$ & $2.0 \pm 0.02$ & $3.0 \pm 0.01$ & $3.0 \pm 0.01$ & $6.0 \pm 0.02$ \\
$\mathrm{~T} . \mathrm{A}(\mathrm{mg} / \mathrm{L})^{*}$ & $0.45 \pm 0.30$ & $0.45 \pm 0.30$ & $0.40 \pm 0.20$ & $0.42 \pm 0.20$ & $0.38 \pm 0.20$ & $0.25 \pm 0.10$ \\
Temp $\left({ }^{\circ} \mathrm{c}\right)$ & $23.5 \pm 0.03$ & $23.00 \pm 0.01$ & $23.5 \pm 0.03$ & $23.0 \pm 0.01$ & $23.0 \pm 0.01$ & $23.0 \pm 0.01$
\end{tabular}

\footnotetext{
* Mean values for water quality with significant difference $(\mathrm{P}<0.05)$.

$\mathrm{DO}=$ Dissolved Oxygen

T.A $=$ Total Ammonia
}

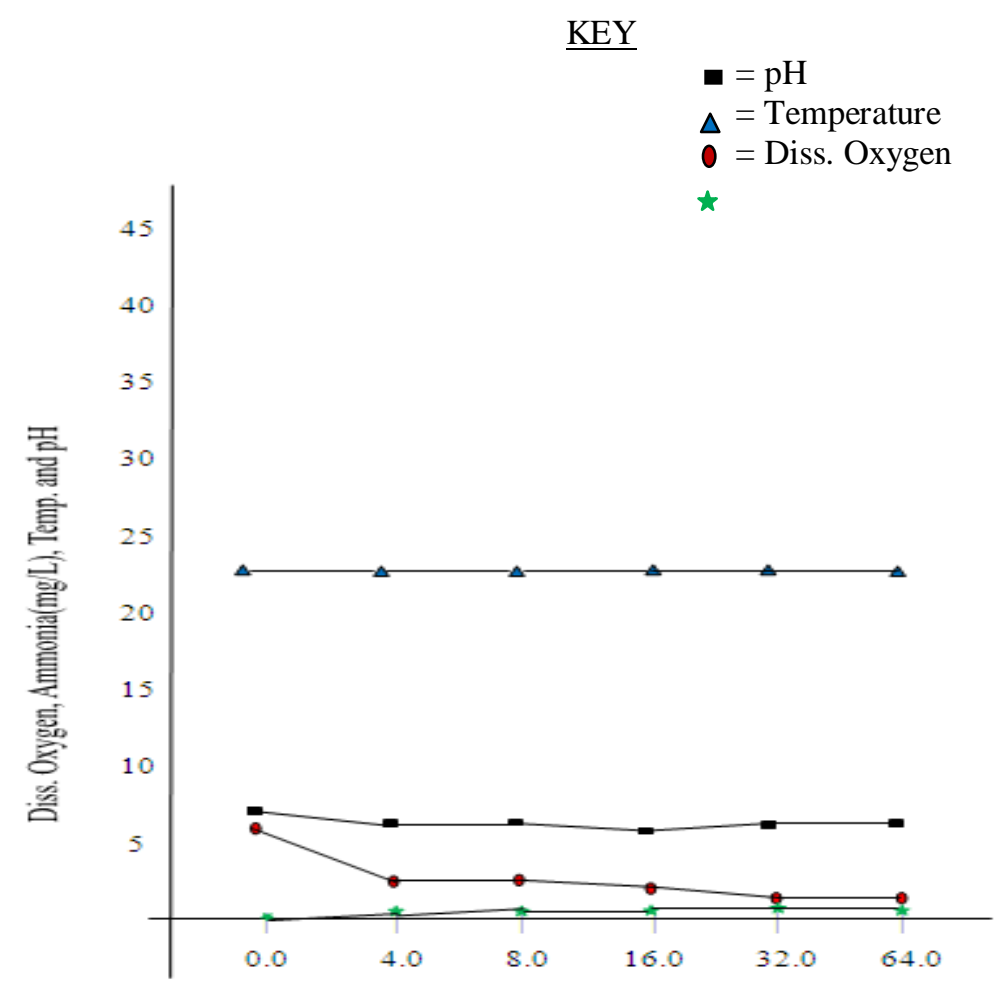

Concentrations $(\mathrm{g} / \mathrm{L})$

Figure 3: The relation between the different concentrations of fruit extract of B. aegyptiaca and diss. Oxygen, ammonia, nitrite and $\mathrm{pH}$.

\section{Conclusion}

The study has shown that the aqueous extract of mesocarp of Balanites aegyptiaca was toxic to African catfish (Clarias gariepinus) with $96-\mathrm{hr} \mathrm{LC}_{50}$ value of $12.59 \mathrm{~g} / \mathrm{L}$. The phytochemical screening of the mesocarp aqueous extract of Balanites aegyptiaca revealed that it contained saponins, tannins, flavonoids, carbohydrate and cardiac glycosides as the active ingredients that give the plant its potency. The toxic effects were reflected in the reduction in some of the haematological parameters of the test fish. Water physico-chemical parameters were also affected by the fruit extract and led to stress factors that were reflected in behaviours like restlessness, increased respiratory rate, gulping of air and loss of balance of the test fish. Therefore the use of the fruit extract 
could lead to contamination and disruption of an ecological system, thus posing great threat to fish and other non-target organisms.

\section{References}

[1]. Abrahamsson, T. and Nilson, S. (1975). Effects of nerve sectioning and drugs onthe catecholamine content in the spleen of the Cod (Gadus morhua),Comparative Biochemistry and physiology 51: 2231.

[2]. Agbon, A.O., Omoniyi, I.J. and Teko, A.A. (2002). Acute toxicity of tobacco (Nicotiana tobaccum) leaf dust on Oreochromis niloticus and haematological changes resulting from sublethal exposure. Journal of Aquatic Science.17(1):5-8

[3]. Annune, P.A., Iyantwwa, I.T., Ebele, S. and Oladumey Y.A.A.(1994).Effect of sublethal concentrations of Zinc on haematological parameters of fresh water fishes, Clarias gariepinus (Burch) and Oreochromis niloticus (Trewavas). Journal of Aquatic Sciences. $9: 1-6$

[4]. Brandt, A. (1984). Fish Catching Meth. of the World: Fishing News Book Ltd.; England; 418p.

[5]. Brown, B. (1980). Haematology: Principles and procedures. Lea and Fabiger Philadelphia. 319pp.

[6]. Cassilas, E. and Smith, L.S. (1977). Effect of stress on blood coagulation and haematology in Rainbow Trout (Salmon Gairdneri). Journal of Fish Biology, 10:481-491.

[7]. Courville, C.B., Courville, D.A. and Halstead, B.W. (1963). Ciguatera - A Neurotoxic Fish Poisoning. Trans. Ame. Neurol. Ass. $10-12,88,204$

[8]. Dubey, P.K., Yogi, M., Bwaradwaj, A., Soni, M.L., Singh, A. and Sachan, A.K. (2011). Balanites aegyptiaca (L.) Del., a SemiArid Forest: A Review. Academic Journal of Plant Sciences 4(1): 12-18.

[9]. Eze, C.C. (1991). Tranquilizing and anaesthetizing effects of some indigenous plants in fish aquaculture. Bachelor Thesis. University of Nigeria, Nsukka Nigeria.

[10]. Duman, E., Dorucu, M. and Sen, D. (2001). Toxic effects of fish feed ( Anamirta cocculus) on Carp (Cyprinus carpio). Online Jounal of Biological sciences, 1 (11), 1093-1094.

[11]. Fagbenro, O.A. (2002). Tilapia fish for thought Inaugural lecture series 32. Federal University of Technology, Akure. p.77.

[12]. Gabriel, U.U., Obomanu, F.G., Orlu, E.E. and Oveh, O.D. (2010). Fulton's condition, organ indices and haematological response of catfish hybrid (Heterobranchus longifilis) and (Clarias gariepinus) to aqueous extracts of leaves of Lepidagathis alopecuroides. Ethiopian Journal of Environmental Studies and Management. Vol. 3, No.1.

[13]. Gonzalez, G. and Schenkel, E.P. (1987). Ichthyotoic activities of Ateleia glazioviana Baill. And Thinouia coriacea Britt. Journal of Ethnopharmacology 20, 81-84

[14]. Harborne, J.B. and Baxter, H. (1993). A handbook of Bioactive compounds from plants, Tay and Francis Press. London U.K., p. 730.Ibu, J.O. and Adeniyi, K.O. (1989). A manual of practical physiology, 3th edition. 17-23pp.

[15]. Kela, S.I., Ogunsisi, R.A., Gobogu, V.C. and Nwude, N. (1989). Screening of some plants for Molluscicidal activity. Revenue Eled. Med. Vet Physe. Trop. 42:195-202.

[16]. Koprucu, S.S., Koprucu, K. and Urail, M.S. (2006). Acute toxicology of synthetic Pyrethroid deltamethrin to fingerling of European catfish ( Silirus glanis L.). Bulletin of Environmental Contamination and Toxicology, 76: 59-65.

[17]. Koyama, J. and Ozaki, H. (1984). Haematological changes of fish exposed to low concentration of Cadmium in the water. Bullentine of Japanese Society of scientific fisheries. 50: 199-203.

[18]. Lawanyawudhi, K. (1982). Rotenone and the fisheries. Thai. Fish Gaz., 35, 4, $411-419$.

[19]. Liang, A. (2009). Zebrafish - useful model for pharmacodynamics and toxicity screening of traditional Chinese medicine Zhongguo Zhong Yao za Zhi, 34(22): 2839-42.

[20]. Mgbenka, B.O. and Ejiofor, E.N. (1998). Effects of extract of dried leaves of Erythrophleom sauveolens as anaesthetics on Clariid catfish. Journal of Applied Aquaculture. 8(4): 73-80.

[21]. Moretti, C. and Grenard P. (1982). Les nivrees ou Plantes ichthyotoxiques de la Guyane France. Journal of Ethnopharmacology, 6, 139-160.

[22]. Olufayo, M.O. (2009). Haematological characteristics of Clarias gariepinus juveniles exposed to Derris elliptica root powder. African Journal of Food, Agriculture, Nutrition and Development. Vol. 9., No. 3

[23]. Omoniyi, I.A., Agbon, A.O. and Sodunke, S.A. (2002). Effect of lethal and sublethal concentrations of tobacco (Nicotiana tobaccum) leaf dust extract on weight and hematological changes in Clarias gariepinus. Journal of Aquatic Sci.Environ. Manage. 6(2):37-41.

[24]. Omoregie, E. and Onuogu, V. (2000). Growth and survival of the cyprinid (Aphyosenion gaidneri) exposed to water extracts of Balanites aegyptiaca and Azadirachta indica. Haudard Medicus, XLIII (2); 24-29.

[25]. Omozusi, B.B., Fagbenro, O.A. and Adebayo, O.T. (2000). Toxicity of alkaline salt(trona) to hybrid catfish (Clarias gariepinus $x$ Heterobranchus bidorsalis) fingerlings. European Aquaculture Society. Special Publication Oostende, Belgium. 28:525.

[26]. Onusiriuka, B. and Ufodike, E.B.C. (1994). Acute toxicity of water extracts of barks of Balanites aegyptiaca and Kigelia africana to Oreochromis niloticus (L), Aquaculture and fisheries management 25:873-879.Redmond, W. A. (2007). Alkaloides, Tannins. Microsoft @ Student.2008 DVD)

[27]. Sprague, J.B. (1973). The ABC's of Pollutant bioassays using fish. In: J. Cairus and K.L. Dickson (Eds), Biological Methods for the Assessment of Water Quality. American Society for Testing and Materials, No. 528, Philadelphia, pp 6-30. Teixeira, J.R.M., Lapa, A.J., Soucar, C. and Valle, J. R. (1984). Timbos. Ichthyotoxic plants used by Brazilian Indians. Journal of Ethnopharmacology 10, 311-318.

[28]. Teugels, G.G. (1986). A systematic revision of the African species of the genus Clarias (Pisces; Clariidae). Ann. Mus. R. Afr. Centr., Sci. Zool., 247:199p.

[29]. Trease, A.E. and Evans, W.C. (1989). A Textbook of pharmacognosy, $13^{\text {th }}$ Edition, Bailliere Tindall, London.

[30]. U.N.E.P. (United Nations Environmental Programme, 1989). Estimation of the acute lethal toxicity of pollutants to Marine fish anf invertebrates. Reference methods for Marine Pollution Studies No. 43, 27pp

[31]. Van Vuren, J.H.J. (1986). The effects of toxicants on the haematology of beo unbratus. Comparative Biochemistry and physiology, 83C:155-159.

[32]. Wang, H.K., Liu, S.Y., Hwang, K.M., Tarloy, G. and Lee, K.H. (1994). Antitumor agents 53. Syntheesis of novel water-soluble 7(aminoacylhydrazono)-formyl camptothecins with potent inhibition of DNA toposomerase I. Bioorg. Med. Chem. 2:1397-403.

[33]. Yadav, R.P. and Singh A. (2009). Toxic effects of crotocaudin extracted from the medicinal plant Croton tiglium. Z Naturforsch. 65(5-6):327-36 